\title{
NONOPERATIVE VERSUS OPERATIVE TREATMENT FOR THORACOLUMBAR JUNCTION BURST FRACTURE WITHOUT NEUROLOGIC DEFICT (ABSTRACT)*. THESIS. SAO PAULO, 2006.
}

\section{ALEXANDRE JOSÉ REIS ELIAS**}

Objectives: Review the current, extensive, literature on this topic in order to analyze whether the radiographic criteria mentioned in several studies (kyphosis, wegding of the vertebra, spinal canal compression, and ligament lesion) can be used to indicate instability of the burst fracture and the need for surgical treatment in patients without neurological deficit.

Methods: We performed online searches of the Medline, LILACS, and Cochrane Library. Studies that were classified as being of interest were those that met the following inclusion criteria: adult patients; Dennis burst-type or Magerl A3 fracture affecting the thoracolumbar spinal segments; single level, non-pathological or osteoporotic fracture; and normal neurological examination.

Results: The final selection included 80 studies that discuss conservative or surgical treatment. Iden- tified 2 presenting Class II evidence in the comparison between conservative and surgical treatment. In the first study, at the end of the 24-month follow-up period, the functional result was the same in both groups. In the second study, the functional capacity was evaluated using of the Roland and Morris index, and the unoperated patients presented higher indices.

Conclusions: Regardless of the radiographic parameters analyzed, there is no evidence, in the studies we reviewed, that surgical treatment is more beneficial than is conservative treatment in individuals with thoracolumbar burst fracture and presenting no neurological deficit. Such studies should involve patients presenting burst fractures that are radiographically characterized as stable.

KEY WORDS: burst fracture, thoracolumbar spine, systematic review, treatment.

* Revisão Sistemática comparando o tratamento conservador e o cirúrgico nos pacientes com fratura da coluna toracolombar, tipo explosão com exame neurológico normal (Resumo). Tese de Mestrado, Universidade Federal de São Paulo (Área: Neurocirurgia). Orientador: Mirto N. Prandini

** Address: Avenida Faria Lima, 2413 / 22, 01452-000 São Paulo SP, Brasil.

\section{EFFECTS OF HYPERTONIC SALINE SOLUTION AND MANNITOL IN ACUTE INTRACRANIAL HYPERTENSION IN RABBITS (ABSTRACT)*. DISSERTATION. RECIFE, 2006.}

\author{
JOACIL CARLOS DA SILVA JR**
}

Introduction: Medical management of brain edema and elevated intracranial pressure (ICP) is a crucial challenge in neurosurgical practice. Depending on the cause, the treatments for brain edema fall into three categories: stabilization of the blood brain barrier, depletion of brain water, and surgical decompression. Although mannitol is the mainstay of hyperosmolar therapy hypertonic saline (HS) is emerging as an effective alternative to traditional osmotic agents.

Methods: Experimental elevated ICP $(50 \mathrm{mmHg})$ was induced in rabbits using an intracranial balloon. The effects of mannitol and hypertonic saline $(\mathrm{NaCl}$ $10 \%$ ) was compared in this specific physiopathological model. Twelve animals were divided in three groups (control, HS and mannitol) according to intravenous administration of $\mathrm{NaCl} 0,9 \%, \mathrm{NaCl} 10 \%$ or mannitol $20 \%$ five minutes after the elevation of ICP. The dos- es of $\mathrm{NaCl} 10 \%$ and mannitol $20 \%$ were iso-osmolar. During 90 minutes continuous recording of ICP, mean arterial pressure (MAP) and cerebral perfusion pressure (CPP) was realized.

Results: The control group had a median survival of only 53 minutes, significantly lower than the treated groups $(p=0.0002)$. There was statistical difference between mannitol and $\mathrm{HS}$, the $\mathrm{NaCl} 10 \%$ group had lower values of ICP $(p=0.0116)$ and higher values of MAP $(p<0.0001)$ and CPP $(p<0.0001)$.

Conclusion: The findings demonstrate higher efficacy of the $\mathrm{NaCl} 10 \%$ treatment in this comparison with mannitol $20 \%$. Further efforts should be directed toward development of clinical studies using isoosmotic doses of mannitol and HS in specific etiologies of intracranial hypertension.

KEY WORDS: intracranial pressure, hypertonic saline, mannitol.

* Efeitos de solução salina hipertônica e manitol em coelhos com hipertensão intracraniana aguda (Resumo). Dissertação de Mestrado, Universidade Federal de Pernambuco-UFPE (Área Neuropsiquiatria-Neurociência Experimental). Orientador: Hildo Rocha Cirne de Azevedo Filho.

** Address: R. Agenor Lopes, 424/ AP701, 51021-110 Recife-PE, Brasil (joacil_carlos@hotmail.com). 